\title{
Presumptive Diagnostic of an Intrauterine Transmission of Clostridium Botulinum in a Bovine Fetus
}

\author{
Helge Böhnel $^{1,2}$, Frank Gessler ${ }^{1,3}$ and Hartwig Bostedt ${ }^{4}$ \\ ${ }^{1}$ Institute for Tropical Animal Health, Georg-August-University, Germany \\ ${ }^{2}$ Institute for Applied Biotechnology in the Tropics (IBT), Germany \\ ${ }^{3}$ Miprolab microbiological diagnostics GmbH, Germany
}

${ }^{4}$ Clinics of Obstetrics, Gynecology and Andrology of Large and Small Animals, Veterinary Faculty, Justus-Liebig-University, Gissen, Germany

Correspondence should be addressed to: Helge Böhnel; boehnel@miprolab.com

Received 21 May 2013; Accepted 17 June 2013; Published 30 October 2013

Academic Editor: Masafumi Mukamoto

Copyright (C 2013 Helge Böhnel, Frank Gessler and Hartwig Bostedt. Distributed under Creative Commons CC-BY 3.0

\begin{abstract}
A dairy herd was affected by a disease of unknown origin. Over 12 months standard samples (feces, and blood serum) were taken and tested for Clostridium botulinum, botulinum neurotoxin and partly for botulinum toxin antibodies according to standard international procedures. Finally it was shown that the dramatic clinical situation was caused by botulism in its chronic toxico-infectious form ("visceral botulism"). The main symptoms were reduced milk yield, lameness, an increased mortality in adults and calves, and a general impairment of health of the herd. One special case is reported here. A paralyzed cow aborted after 7 months of pregnancy. The fetus was delivered dead. Diagnostic samples were taken immediately for microbiological investigations. Specimens of the intestinal tract of the cow contained the C. botulinum neurotoxin and vegetative states (combined toxin group ABE). C. botulinum was isolated from specimen of the fetus and toxin group ABE was found in the liver, suggesting an intrauterine infection.
\end{abstract}

Keywords: Clostridium botulinum; Abortion; Intrauterine transmission; Bovine fetus.

\section{Introduction}

The soil bacterium Clostridium (C.) botulinum produces the botulinum neurotoxin (BoNT) (types A-G). In animals apparently mosaic toxin forms (C/D, D/C) prevail (Woudstra et al., 2012). They act directly or indirectly after resorption within the body on neuronal muscular synapses and different regulatory physiological circles, signalling cascades or pathways (Böhnel and Gessler, 2005; Fujinaga et al., 2013; Bercsenyi et al., 2013).The toxins are produced ex vivo in feed, broiler litter, insects, water, or soil and compost (Böhnel and Lube, 2000;

Cite this Article as: Helge Böhnel, Frank Gessler and Hartwig Bostedt (2013), "Presumptive Diagnostic of an Intrauterine Transmission of Clostridium Botulinum in a Bovine Fetus," International Journal of Veterinary Medicine: Research \& Reports, Vol. 2013 (2013), Article ID 747291, DOI: $10.5171 / 2013.747291$ 
AFSSA, 2002; ACMSF, 2006b). When BoNTs are ingested, they are absorbed via the mucous membranes of the digestive tract and transported by the blood to different places of action (Fujinaga et al., 2013). If BoNT acts in a high quantity and in a short time space, it may lead to sudden death without prior clinical signs or severe disease. Less dramatic cases with lower toxin quantities are described as chronic botulism (Graham and Schwarze, 1921). Occasionally animals may recover completely (AFSSA, 2002; ACMSF, 2006b). Nothing is known regarding clinical effects of minimal BoNT doses and longer intoxication times. In a normal situation, the healthy microbiota prevents the growth and toxin production by C. botulinum. Anyway, in some specific cases, these bacteria could multiply and cause an infection of the gastro-intestinal tract. BoNTs may be produced there in vivo, described as "toxico-infection" (AFSSA, 2002; ACMSF, 2006b), intestinal colonisation or enteric infection (ACMSF, 2006a). Bacterial forms and BoNTs were even found in the tonsils (Böhnel et al., 2008). C. botulinum types $C$ and D produce another toxic substance "toxin C2" which is not neurotoxic. It supports the attachment of bacteria to the villi of the intestinal mucosa and the resorption of BoNT by pore forming (Lang et al., 2008). Recently it was shown that another biotoxin, Clostridiolysin S, exhibits a haemolytic activity contributing to clostridial virulence and playing a role in host tissue injury (Gonzales et al., 2010). Cases of toxicoinfections were reported in humans by Meyer as early as 1928 and in infants in 1976 (Midura and Arnon, 1976). In adults similar cases were attributed to bowel surgery and antibiotic treatment (CDC, 2011). In animals, the first reports were in foals in 1967 (Rooney and Prickett) and in chickens in 1978 (Miyazaki and Sakaguchi). At the turn of this century toxico-infections in cattle appeared more important than intoxications in France (AFSSA, 2002) whereas in Great Britain intoxications prevail, toxico-infections are not reported (ACMSF, 2006b). In Germany there has been an increase of bovine botulism cases since the mid nineties of the last century. In the beginning there were only cases of intoxication, but in 1999 the first cases of toxico-infection were diagnosed (Schwagerick and Böhnel, 2001; Böhnel et al., 2001). At present there are estimated more than 1100 cattle farms with confirmed outbreaks in the last 15 years. Their origin remains uncertain. One third is believed to be intoxications with the obvious clinical features of sudden paralysis and death. The rest are toxicoinfections. Here, herd symptoms are reduced milk yield, ruffled fur, engorged veins, unsteady gait, recumbency, tuckedup abdomen, death without recognizable reason especially after calving. The animals show aspects of being ill nourished or completely neglected. Additionally, sudden death or general bad health during months followed by death or even recovery is reported. Other specific symptoms are abortion, or stillbirth. Weak calves may die within weeks (Schwagerick and Böhnel, 2001; Böhnel and Gessler, 2010; Böhnel and Gessler, 2012; Krüger et al., 2012). For the particular animal bulbar paralysis with missing or impaired reflexes in the eyes, ears, or tongue are pathognomonic (Schwagerick and Böhnel, 2001; AFSSA, 2002; ACMSF, 2006b). To separate clinical chronic forms of intoxication lasting for days or weeks (Graham and Schwarze, 1921) from those of intestinal toxicoinfection prevailing for months, the term "visceral botulism" was coined (Böhnel et al., 2001). A classical feature of botulism as intoxication was that only particular animals were affected in one farm. Since the introduction of feeding using total mixed rations (TMR) numerous animals fall sick at the same time (AFSSA, 2002; ACMSF, 2006b). Toxico-infections are a herd problem as the source is common feed (Schwagerick and Böhnel, 2001; Böhnel et al., 2001; AFSSA, 2002).

Acute and chronic forms may be present at the same time in one farm. Concomitant diseases may cause further diffuse clinical features. The general term "botulism" refers to BoNT as the cause of diseases and comprises both intoxication and toxicoinfection with different clinical features. Finally, in general the herd health status improves after a botulinum vaccination in cases of BoNT types C and D 


\author{
(Onderstepoort Biological Products, \\ Onderstepoort, RSA) (personal \\ observations, Krüger et al., 2013).
}

Recently cases of human and bovine botulism on affected cattle farms were reported, where man and animals had fallen sick at the same time by the same BoNT types. Common or zoonotic origins are not yet fully understood (Dressler and Saberi, 2009; Krüger et al., 2012; Rodloff and Krüger, 2012).

\section{Material and Methods}

\section{History}

A farm in Western Germany with about 70 cows lost 135 cows within 4 years. It was one of the few ones which were officially allowed to cultivate and feed genetically modified Bt-maize on a trial basis. This seed contains a genetic insert of Bacillus thuringiensis against the corn borer (Meissle et al., 2011). In 2001 the dairy herd began to show hitherto unspecific symptoms. As no disease could be found initially unknown side effects of the maize were suspected. At this time, discussion on visceral botulism was already an ongoing feature with hundreds of similar cases in Germany (Schwagerick and Böhnel, 2001; Böhnel et al., 2001; Böhnel and Gessler, 2012). This led the farmer to the suspicion of visceral botulism.

\section{Clinical Examinations and Specimen Collection}

Especially as a possible connection with the gene manipulated maize could not be ruled out, from 2002 onwards samples were sent for botulinum laboratory diagnosis and tested for scientific purposes accordingly. Standard samples were feces and blood serum from living animals, inner organs, and additionally content of different parts of the gastro-intestinal tract of dead animals. Feed specimens were examined as well (Table 1). 
Table 1: Results of Laboratory Examinations for Clostridium Botulinum (Neurotoxins, Toxigenic Bacterial Forms, Antibodies) for the Years 2002/2003 of the Afflicted Farm

\begin{tabular}{|c|c|c|c|c|c|c|c|c|c|}
\hline \multirow[t]{2}{*}{$\begin{array}{l}\text { lab. } \\
\text { no. }\end{array}$} & \multirow[t]{2}{*}{$\begin{array}{l}\text { date } \\
\text { sampling }\end{array}$} & \multirow{2}{*}{\multicolumn{2}{|c|}{ sample }} & \multicolumn{2}{|c|}{$\begin{array}{l}\text { toxin } \\
\text { neutralisation }\end{array}$} & \multicolumn{4}{|c|}{ antibody $^{3}$} \\
\hline & & & & tox ${ }^{1}$ & bact $^{2}$ & $\mathrm{~A}$ & B & C & $\mathrm{D}$ \\
\hline 02212 & 17.04 .02 & $\begin{array}{l}\text { corn } \\
\text { grass }\end{array}$ & $\begin{array}{l}\text { silage } 2000 \\
\text { silage } 2001 \\
\text { grain } 2000 \\
\text { silage } 2001\end{array}$ & $\begin{array}{l}- \\
- \\
- \\
-\end{array}$ & $\begin{array}{l}- \\
- \\
- \\
-\end{array}$ & & & & \\
\hline 02318 & 15.05 .02 & $\begin{array}{l}\text { bovine } \\
\text { bovine }\end{array}$ & $\begin{array}{l}\text { blood (frozen) } \\
\text { rumen content } \\
\text { liver } \\
\text { blood (frozen) } \\
\text { rumen content } \\
\text { intestinal content } \\
\text { liver }\end{array}$ & $\begin{array}{l}- \\
- \\
- \\
- \\
- \\
- \\
-\end{array}$ & $\begin{array}{l}- \\
- \\
- \\
- \\
- \\
- \\
-\end{array}$ & & & & \\
\hline 02517 & 24.07 .02 & $\begin{array}{l}\text { bovine } \\
\text { bovine } \\
\text { bovine } \\
\text { bovine } \\
\text { bovine }\end{array}$ & $\begin{array}{l}\text { faeces } \\
\text { blood } \\
\text { faeces } \\
\text { blood } \\
\text { faeces } \\
\text { blood } \\
\text { faeces } \\
\text { blood } \\
\text { faeces } \\
\text { blood }\end{array}$ & - & $\begin{array}{l}- \\
- \\
- \\
- \\
-\end{array}$ & $\begin{array}{l}- \\
x\end{array}$ & $\begin{array}{l}- \\
x\end{array}$ & - & $\begin{array}{l}- \\
- \\
- \\
-\end{array}$ \\
\hline 02596 & 23.8 .02 & $\begin{array}{l}\text { bovine } \\
\text { calf }\end{array}$ & $\begin{array}{l}\text { rumen content } \\
\text { intestinal content } \\
\text { liver } \\
\text { faeces }\end{array}$ & $\begin{array}{l}- \\
- \\
\mathrm{CD} \\
-\end{array}$ & $\begin{array}{l}+ \\
+ \\
- \\
-\end{array}$ & & & & \\
\hline 03172 & 25.02 .03 & $\begin{array}{l}\text { bovine } \\
\text { bovine } \\
\text { bovine }\end{array}$ & $\begin{array}{l}\text { rumen content } \\
\text { liver } \\
\text { small intestine } \\
\text { content } \\
\text { liver } \\
\text { large intestine } \\
\text { content } \\
\text { liver }\end{array}$ & $\begin{array}{l} \\
- \\
- \\
- \\
- \\
-\end{array}$ & $\begin{array}{l}\text { CD } \\
- \\
- \\
- \\
C D \\
C D\end{array}$ & & & & \\
\hline \multirow[t]{2}{*}{03223} & 05.03 .03 & bovine & $\begin{array}{l}\text { rumen content } \\
\text { small intestine } \\
\text { cont. } \\
\text { large intestine } \\
\text { cont. } \\
\text { liver } \\
\text { spleen } \\
\text { tonsils } \\
\text { lochia }\end{array}$ & $\begin{array}{l}+ \\
- \\
\text { ABE } \\
- \\
- \\
- \\
-\end{array}$ & $\begin{array}{l}\text { ABE } \\
- \\
- \\
- \\
- \\
- \\
-\end{array}$ & & & & \\
\hline & & foetus & $\begin{array}{l}\text { liver } \\
\text { spleen }\end{array}$ & - & $\begin{array}{l}\text { ABE } \\
-\end{array}$ & & & & \\
\hline 03259 & 18.03 .03 & $\begin{array}{l}\text { bovine } \\
\text { bovine } \\
\text { bovine } \\
\text { bovine }\end{array}$ & $\begin{array}{lr}\text { large intestine } \\
\text { content large } \\
\text { intestine content } \\
\text { large intestine }\end{array}$ & $\begin{array}{l}\text { ABE } \\
- \\
- \\
-\end{array}$ & $\begin{array}{l}\mathrm{ABE} \\
- \\
- \\
\mathrm{ABE}\end{array}$ & & & & \\
\hline
\end{tabular}




\begin{tabular}{|c|c|c|c|c|c|c|c|c|c|}
\hline & & & $\begin{array}{l}\text { content large } \\
\text { intestine content }\end{array}$ & & & & & & \\
\hline 03633 & 24.6 .03 & $\begin{array}{l}\text { bovine } \\
\text { bovine } \\
\text { bovine } \\
\text { bovine } \\
\text { bovine }\end{array}$ & $\begin{array}{l}\text { faeces } \\
\text { blood } \\
\text { faeces } \\
\text { blood } \\
\text { faeces } \\
\text { blood } \\
\text { faeces } \\
\text { blood } \\
\text { faeces } \\
\text { blood }\end{array}$ & $\begin{array}{l}- \\
- \\
C D \\
C D \\
-\end{array}$ & $\begin{array}{l}\mathrm{ABE} \\
\mathrm{ABE} \\
- \\
+ \\
\mathrm{ABE}\end{array}$ & $\begin{array}{l}\mathrm{xxx} \\
\mathrm{xxx} \\
\mathrm{x} \\
\mathrm{xxx} \\
\mathrm{xxx}\end{array}$ & $\begin{array}{l}\mathrm{xxx} \\
\mathrm{xxx} \\
\mathrm{x} \\
\mathrm{xx} \\
\mathrm{xx}\end{array}$ & $\begin{array}{l}- \\
X\end{array}$ & $\mathrm{X}$ \\
\hline
\end{tabular}

- = negative; + = toxic, no neutralisation done; $\mathrm{ABE}$ resp. $\mathrm{CD}=$ toxin group specific neutralization; tox $^{1}=$ direct toxin elution; bact ${ }^{2}=$ enrichment culture of toxigenic bacteria; antibody levels ${ }^{3}=$ arbitrary from negative to strongly positive $(-, \mathrm{x}, \mathrm{xx}, \mathrm{xxx})$, Cont. $=$ content

\section{Bold: Actual Reported Case}

In May 2003 a sick pregnant cow (Holstein Frisian breed, 9 years old, $6^{\text {th }}$ pregnancy (197th day) was sent to the Clinic of Obstetrics of the Veterinary Faculty, University of Gießen. The animal (No. 03223) arrived in the clinic completely recumbent. The clinical picture was that of a flaccid paralysis after unsuccessful treatment for milk fever. At the entrance examination there were no other signs of a specific disease. The delivery had already started. Finally, the dead fetus was developed per vias naturales. Parts of the fetal envelopes and placenta were delivered immediately. The aspect of fetus and fetal envelopes caused not increase of concern. The clinical feature was first interpreted as an acute form of botulism, as a previous treatment for milk fever at the farm had been attempted without success. The examinations gave no indication of any differential diagnosis which would lead to abortion in the $7^{\text {th }}$ month of pregnancy.

\section{Laboratory Diagnostic}

The fetus and the euthanized cow were sent unopened to the adjacent Institute for Veterinary Pathology, University of Gießen, for immediate further action. The fetus had been cooled and was examined next morning, the carcass of the cow immediately after euthanization. Due to the importance of the case, mal-nutrition and possible infections leading to abortion had to be excluded as cause of illness. Of the cow liver, lungs, spleen, kidney and placenta were tested bacteriologically on "ordinary" bacterial content including Listeria, Brucella, excluding Campylobacter, Chlamydia, Coxiella, Histophilus somni. Intestines were tested additionally for clostridia and by ZiehlNeelsen staining. Fetal specimens were tested additionally for viral cytotoxicity on bovine and ovine cells with consecutive pestivirus immunofluorescence. Samples for presumptive botulism were taken during autopsy under standard working conditions to avoid post-mortal contaminations. They were again immediately cooled or frozen and sent so to our laboratory where they arrived within $24 \mathrm{~h}$. Transport was less than $24 \mathrm{~h}$. The bacteriological examinations started right after arrival of the specimens. As there are no international reference methods for laboratory testing of supposed botulinum samples, the bacteriological diagnosis was done according to AOAC International methods (2001) by mouse bioassay. Other tests were at that time and are not yet suitable for standard routine diagnosis. PCR may help to identify the presence of toxigenic genes. Toxins are not targeted (Lindström and Korkeala, 2006; Cai et al., 2007; Dorner et al., 2013). In short, BoNT is directly eluted out of the sample by gelatine-phosphate buffer $(\mathrm{pH}$ 6.2) overnight. Bacterial forms or spores are cultured in liquid enrichment medium (Reinforced Clostridial Medium (Merck, Darmstadt) under anaerobic conditions (48 $\mathrm{h} / 37^{\circ} \mathrm{C}$ ). Eluted or formed BoNT is tested by injecting $0.5 \mathrm{ml}$ i.p. each into a pair of mice. The animals are observed for clinical 
signs of botulism and death for $96 \mathrm{~h}$. Toxic specimens are mixed with specific botulinum antitoxins to eventually cause a neutralisation of the BoNT (20 min, room temperature) and injected as described above. Surviving animals indicate the presence of specific BoNT. For animal welfare issues mono-specific, i.e. polyclonal antibodies against a single toxin type for toxin routine neutralisation in our laboratory were mixed in two groups A, B, and $E$, and $C$ and $D$ respectively, referred to as combined toxin groups $\mathrm{ABE}$ and $\mathrm{CD}$. Further differentiation of particular toxins in positive samples was not done.

The incoming specimens of a farm are tested in an arbitrary order by toxin elution and enrichment culture. For practical reasons any further testing of additional specimens was abandoned once a sample gave a conclusive positive result for $a$ specific animal. Due to the shortcoming of the mouse bio-assay this result was used then as indicative for the result of the whole herd as well. Blood samples were not tested for bacteria or toxin. Serum antibodies against botulinum toxins A, B, C, and $D$ were tested by a mono-specific ELISA. An arbitrary quantification was done from negative/- to strong/xxx (Mawhinney et al., 2011). All legal aspects concerning animal tests were respected.

\section{Results and Discussion}

Retrospective studies have inherent weaknesses, but these provide the only possible access to botulinum problems as there is no chance of obtaining permission from ethics committees to undertake specific animal tests. To copy natural conditions of multi-factorial diseases with partly unknown factors is an almost impossible task.

Since at least 2002 laboratory tests revealed an impact of botulism in the dairy herd. Initially $C$. botulinum toxin group CD was found. Later-on toxin group $\mathrm{ABE}$ appeared as well. Antibody tests showed an intensive contact mainly with BoNT types A and $\mathrm{B}$.
Blood tests of the cow presented to the clinic showed a serious disturbance of electrolyte homeostasis type 1 (calcium $0.45 \mathrm{mmol}$, anorganic phosphorus 0.5 mmol) (Bostedt, 1973). The cow was euthanized after abortion by order of the owner.

The pathological examinations of the cow specimens revealed an intensive haemostasis in liver, spleen, and kidneys. The lungs showed an important alveolar emphysema, the uterus retentio secundinarum and endometritis. The placenta of the fetus showed focal edema. Virological tests were negative (M. Reinacher, personal communication).

All organs harboured haemolytic and nonhaemolytic $E$. coli, the placenta few Streptococcus epidermidis, $\alpha$-haemolytic streptococci and Acinetobacter spp. (C. Ewers, personal communication). Virological tests of the fetus were negative (C. Förster, personal communication).

The botulinum test results are reported in detail (Table 1). The outcome of the tests showed that toxigenic $C$. botulinum had appeared in the farm and became manifest. Together with appropriate clinical symptoms it was detected for the first time mid-2002. In the first year $C$. botulinum toxin group CD was found by proof of BoNT or bacterial forms. Afterwards, toxin group ABE was diagnosed as well and became more prevalent. Antibodies were predominantly types $A$ and B. Visceral botulism was presumed and finally diagnosed on the basis of clinical signs and elimination of other diseases as a farm diagnosis. The bacteriological findings supported this diagnosis.

In March 2003 the botulinum tests for the cow No. 03223 showed bacterial forms of $C$. botulinum toxin group $\mathrm{ABE}$ in the rumen. BoNT group ABE was neutralised in the large intestine. The hemolysed blood sample was not suited for ELISA. The rumen sample provoked specific symptoms for botulism in mice and was not further neutralised. This is consistent with those findings of visceral botulism, one of the specific symptoms being abortion, 
stillbirth, or weak nonviable calves, which may die within weeks (Schwagerick and Böhnel, 2001; Böhnel et al., 2001). The presence of bacterial forms of $C$. botulinum in the intestinal tract together with the depicted clinical symptoms and the absence of other pathogens is a strong support of suspected botulism. In rare cases $C$. botulinum bacteria may be found in healthy animals (own not published results). The proof of botulinum toxin, however, is confirmative.

The liver of the freshly dead fetus contained bacterial states of $C$. botulinum toxin group $\mathrm{ABE}$.

To the best of our knowledge this is the first time where botulinum bacteria (toxin group $\mathrm{ABE}$ ) were diagnosed in the liver of a fetus of an infected cow. Thus, an intrauterine infection has to be presumed. Despite the syndesmochorial placenta of the cow an intrauterine transfer of $C$. botulinum from mother to the fetus may not be excluded. However, a connection with the endometritis and placentitis due to an ascending vaginal infection together with E. coli could be postulated as well. This is similar to the presence of botulinum toxin in milk of a cow suffering by an untreatable mastitis (Böhnel et al., 2005). Recently, the proof of $C$. botulinum and botulinum toxin in milk and udder tissue of cows with botulism was reported (Böhnel and Gessler, 2013). In an a case of infant botulism caused by $C$. baratii type $\mathrm{F}$ toxin presenting at 54 hours of life the authors argued for a congenital infection, but rejected this idea as it had never been described before (Keet et al., 2005).

Further tests are necessary to evaluate $C$. botulinum infections and the pharmacological actions of botulinum toxin as a possible cause of stillbirth or calf mortality within the first week of life.

\section{Acknowledgement}

The authors thank all staff members and PhD students for their excellent clinical and laboratory work.

\section{Conflict of Interest Statement}

The authors of this paper have no financial, personal or other relationships with other people or organizations that could inappropriately bias the content of the paper.

\section{References}

ACMSF (Advisory Committee on the Microbiological Safety of Food), (2006a) Ad Hoc Group on Infant Botulism. "Report on Minimally Processed Infant Weaning Foods and the Risk of Infant Botulism," [Retrieved April 20, 2013]. http://www.food.gov.uk/multimedia/pdfs /infantbotulismreport.pdf

ACMSF (Advisory Committee on the Microbiological Safety of Food), (2006 B) Ad Hoc Group on Botulism in Cattle. "Report on Botulism in Cattle," London, Food Standards Agency, [Retrieved April 20, 2013].

http://www.food.gov.uk/multimedia/pdfs /botulismincattlereport1206.pdf.

AFSSA (Agence Française de Securité Sanitaire des Aliments) (2002) "Rapport sur le Botulisme D'origine Aviaire et Bovine," Maisons-Alfort; 82 p, [Retrieved April 20, 2013]. http://www.avicampus.fr/PDF/botulisme AFSSA.pdf

AOAC International (2001) AOAC official Method 977.26 (Sec 17.07.01) 'Clostridium Botulinum and its Toxins in Foods,' Official Method of Analysis, 17th ed., AOAC International, Gaithersburg, $M d$.

Bercsenyi, K., Giribaldi, F. \& Schiavo, G. (2013). "The Elusive Compass of Clostridial Neurotoxins: Deciding When and Where to Go?," In: Rummel, A., Binz, T. (Eds), Botulinum Toxins. Current Topics in Microbiology, 364. Springer, Berlin, Pp. 91113.

Böhnel, H. \& Gessler, F. (2005). "Botulinum Toxins - Cause of Botulism and Systemic Diseases?," Veterinary Research Communication, 29 313-345. 
Böhnel, H. \& Gessler, F. (2010). 'Clostridial Neurotoxicoses - Tetanus and Botulism,' In: Gyles, C. L., Prescott, J. F., Songer, J. G. and Thoen, C. O. (Eds), Pathogenesis of Bacterial Infections in Animals, 4th Ed., Wiley-Blackwell, Ames (Iowa), Pp. 189-202.

Böhnel, H. \& Gessler, F. (2012). "Hinweise Zum Vorkommen von Rinderbotulismus in Deutschland Anhand von Laboruntersuchungen der Jahre 19962010," Tierärztliche Umschau, 67 251-256.

Böhnel, H. \& Gessler, F. (2013). "Presence of Clostridium Botulinum and Botulinum Toxin in Milk and Udder Tissue of Dairy Cows with Suspected Botulism," Veterinary Record, 172397.

Böhnel, H. \& Lube, K. (2000). "Clostridium Botulinum and Biocompost. A Contribution to the Analysis of Potential Health Hazards Caused by Bio-Waste Recycling," Journal of Veterinary Medicine B, 47 785-795.

Böhnel, H., Neufeld, B. \& Gessler, F. (2005). "Botulinum Neurotoxin Type B in Milk From a Cow Affected by Visceral Botulism," Veterinary Journal, 169 124-125.

Böhnel, H., Schwagerick, B. \& Gessler, F. (2001). "Visceral Botulism - A New Form of Bovine Clostridium Botulinum Toxication," Journal of Veterinary Medicine A, 48 373383.

Böhnel, H., Wagner, C. \& Gessler, F. (2008). "Tonsils - Place of Botulinum Toxin Production. Results of Routine Laboratory Diagnosis in Farm Animals," Veterinary Microbiology, 130 403-409.

Bostedt, H. (1973). 'Untersuchungen von Blutserum Festliegender Rinder Im Frühen Puerperalstadium. (1. Mitt.),' Berliner und Münchener Tierärztliche Wochenschrift, 86 344-449.

Cai, S., Singh, B. R. \& Sharm, S. (2007). "Botulism Diagnostics: From Clinical Symptoms to in Vitro Assays," Critical Reviews in Microbiology, 33 109-125.
CDC (Centers for Disease Control and Prevention) (2011). "Botulism (Clostridium Botulinum) 2011 Case Definition," Centers for Disease Control and Prevention, Atlanta, [Retrieved April 20, 2013]. http://www.cdc.gov/osels/ph_surveillance /nndss/casedef/botulism_current.htm.

Dorner, M. B., Schulz, K. M., Kull, S. \& Dorner, B. G. (2013). "Complexity of Botulinum Neurotoxins: Challenges for Detection Technology," In: Rummel, A. \& Binz, T. (Eds), Botulinum Toxins. Current Topics in Microbiology and Immunology, 364. Springer, Berlin, Pp. 219-255.

Dressler, D. \& Saberi, F. A. (2009). "Botulinum Toxin: Vom Medikament Zum Toxin ....," Fortschritte in Neurologie und Psychiatrie, 77 (Suppl 1) 549-554.

Fujinaga, Y., Sugawara, Y. \& Matsumura, T. (2013). "Uptake of Botulinum Neurotoxin in the Intestine," In: Rummel, A. and Binz, T. (Eds), Botulinum Toxins. Current Topics in Microbiology and Immunology, 364. Springer, Berlin, Pp. 45-59.

Gonzales, D. J., Lee, S. W., Hensler, M. E., Markley, A. L., Dahesh, S., Mitchell, D. A., Bandeira, N., Nizet, V., Dixon, J. E. \& Dorrestein, P. C. (2010). "Clostridiolysin S, A Post-Translationally Modified Biotoxin from Clostridium Botulinum," Journal of Biological Chemistry, 285 28220-28228.

Graham, R. \& Schwarze, H. R. (1921). "Botulism in Cattle," Journal of Bacteriology, 6 69-83.

Keet, C. A., Fox, C. K., Margeta, M., Marco, E., Shane, A. L., Dearmond, S. J., Strober, J. P. \& Miller, S. P. (2005). "Infant Botulism, Type F, Presenting at 54 Hours of Life," Pediatric Neurology, 32 193-196.

Krüger, M., Große-Herrenthey, A., Schrödl, W., Gerlach, A. \& Rodloff, A. (2012). "Visceral Botulism at Dairy Farms in Schleswig-Holstein, Germany - Prevalence of Clostridium Botulinum in Feces of Cows, in Animal Feed, in Feces of Farmers, and in House Dust," Anaerobe, 18 221-223. 
Krüger, M., Skau, M., Shehata, A. A., Schrödl, W. (2013). "Efficacy of Clostridium Botulinum Types $\mathrm{C}$ and $\mathrm{D}$ Toxoid Vaccination in Danish Cows," Anaerobe.

Lang, A. E., Neumeyer, T., Sun, J., Collier, R. J., Benz, R. \& Aktories, K. (2008). "Amino Acid Residues Involved in Membrane Insertion and Pore Formation of Clostridium Botulinum C2 Toxin," Biochemistry 47 8406-8413.

Lindström, M. \& Korkeala, H. (2006). "Laboratory Diagnostics of Botulism," Clinical Microbiology Reviews, 19 298-314.

Mawhinney, I., Palmer, D., Gessler, F., Cranwell, M., Foyle, L., Otter, A., Payne, J. \& Strugnell, B. (2011). "Investigation of Serology for Diagnosis of Outbreaks of Botulism in Cattle," Veterinary Journal, 192 382-384.

Meissle, M., Romeis, J. \& Bigler, F. (2011). "Bt Maize and Integrated Pest Management - A European Perspective," Pest Management Science, 67, 1049-1058.

Meyer, K. F. (1928). 'Botulismus,' In: Kolle, W., Kraus, R. and Uhlenhuth, P. (Eds), Handbuch Der Pathogenen Mikroorganismen, 3rd Ed. Vol. IV/2, Fischer und Urban\&Schwarzenberg, Jena, Pp.12691364.

Midura, T. F. \& Arnon, S. S. (1976). "Infant Botulism, Identification of Clostridium
Botulinum and Its Toxins in Faeces," The Lancet, Ii 934-936.

Miyazaki, S. \& Sakaguchi, G. (1978). "Experimental Botulism in Chickens. The Cecum as the Site of Production and Absorption of Botulinum Toxin," Japanese Journal of Medical Science and Biology, 31 1-15.

Payne, J. H., Hogg, R. A., Otter, A., Roest, I. J. \& Livesey, C. T. (2011). "Emergence of Suspected Type D Botulism in Ruminants in England and Wales (2001 to 2009), Associated with Exposure to Broiler Litter," Veterinary Record, 168 641-643.

Rodloff, A. C. \& Krueger, M. (2012). "Chronic Clostridium Botulinum Infection in Farmers," Anaerobe, 18 SI 226-228.

Rooney, J. R. \& Prickett, M. E. (1967). 'Shaker Foal Syndrome,' Modern Veterinary Practice, 48 44-45.

Schwagerick, B. \& Böhnel, H. (2001). "Eine Chronische Erkrankung Bei Milchkühen Mit Nachweis von Botulinumtoxin - Eine Fallstudie," Der Praktische Tierarzt, 82 516524.

Woudstra, C., Skarin, H., Anniballi, F., Fenicia, L., Bano, L., Drigo, I., Koene, M., Baeyon-Auboyer, M. H., Buffereau, J. P., De Medici, D. \& Fach, P. (2012). "Neurotoxin Gene Profiling of Clostridium Botulinum Types C and D Native to Different Countries within Europe," Applied and Environmental Microbiology, 78 3120-3127. 